International Journal of Linguistics, Literature and Translation (IJLLT)

ISSN: 2617-0299 (Online); ISSN: 2708-0099 (Print)

DOI: $10.32996 / \mathrm{ijllt}$

Journal Homepage: www.al-kindipublisher.com/index.php/ijllt

\title{
Insubordinate Conditional Clauses Formed by Japanese Conjunction -ba
}

Sang Zhonglin

PhD student, Graduate School of Humanities, Nagoya University, Nagoya, Japan

Corresponding Author: Sang Zhonglin, E-mail: sangzhonglin323@gmail.com

ARTICLE INFORMATION

Received: December 15, 2020

Accepted: February 10, 2021

Volume: 4

Issue: 2

DOI: 10.32996/ijllt.2021.4.2.6

\section{KEYWORDS}

Insubordination, conditional clauses, Japanese, -ba, discourse functions

\section{ABSTRACT}

Insubordination describes the phenomenon that a subordinate clause is used independently as a main clause. Insubordinate clauses endorse discourse functions alone without connecting with any apodosis. Many researchers studied this phenomenon from a typology perspective, clarifying the discourse functions and forming mechanism. However, those studies pursuit the cross-language features too much, investigating large numbers of languages and source constructions. As a result, their conclusion may not fit a specific language or construction. This paper aims to verify and complement the classification of one of the typology studies: Evans (2007), based on the investigation of the insubordinate conditional clauses formed by Japanese conjunction -ba, through the Balanced Corpus of Contemporary Written Japanese (BCCWJ). The investigation result showed that Evans' (2007) classification fit the insubordinate -ba-clauses to some extent with a slight adjustment. Specifically, the types of "indirection and interpersonal control" and "modal insubordination" were combined as Type A, which was named "modal insubordination". Meanwhile, a new discourse function, "requirement of further information" was added to the other type, "signaling presupposed material" to compose Type B, which was named "signaling presupposed material". In Type A, the insubordinate -ba-clauses function as two subtypes, which are "epistemic and evidential meanings" and "deontic meanings". Those two subtypes relate to each other by expressing or requiring evaluation towards the conditional clauses. Meanwhile, Type B has two subtype functions as well, which are "disagreement with assertions by the previous speaker" and "requirement of further information". Both subtypes are formed by the process of providing a contrastive condition and requesting a response. Two further related issues were also discussed. The insubordinate -ba-clauses endorsing Type B functions appear to have some similarities with another type of insubordinate clause that was pointed out by other typology studies. However, they indeed differ from each other in their discourse functions and forming mechanisms. Moreover, as to the -ba-clauses, the distinction between Type A and Type B was found to be more apparent when analyzed from a functional perspective rather than a structural perspective. Those arguments complement Evans' (2007) classification. This study shows its significance in verifying Evans'(2007) viewpoint by the Japanese language as a unique Asian language. Such verification is necessary because Evans' research was carried out mostly based on Indo-European languages. It is also implicated that a theory of general linguistics can contribute to studying an individual language in observing it from an outside perspective.

\section{Introduction}

Insubordination, which is defined as "the conventionalized main clause use of what, on prima facie grounds, appear to be formally subordinate clauses" (Evans, 2007, p. 367), has raised considerable interest recently. It describes the process where a subordinate clause is used independently as a main clause. This phenomenon contrasts with the common knowledge that a subordinate clause should depend on the main clause to be used. Insubordination is a diachronic concept. Its synchronic

K C AL-KINDI CENTER R D FOR RESEARCH AND R D DEVELOPMENT Your gateway to world-class research

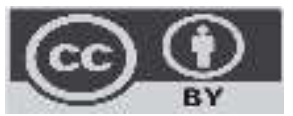

Published by Al-Kindi Center for Research and Development. Copyright (c) the author(s). This open access article is distributed under a Creative Commons Attribution (CC-BY) 4.0 license 
products are insubordinate clauses, which were called "insubordinated constructions" in Evans (2009). Evans (2007) firstly raised the definition of insubordination by investigating various languages towards a topology perspective. He clarified the historical trajectory leading to insubordination, showing that insubordination began from the ellipsis of the main clause. He also summarized the source constructions that cause insubordination, including adverbial clauses, embedded clauses with subordinate word order, and some other subordinate constructions.

Other researchers such as Mithun (2008) and Cristofaro (2016) also studied this phenomenon. Mithun investigated two languages that were not mentioned in Evans (2007): Navajo and Central Alaskan Yup'ik. She found another routine leading to insubordination, which she defined as the extension of the dependency marker. That is, the marker which marks the dependency relation between the subordinate clause and the main clause extends its function to a larger unit. It turns to mark the dependency relation between the subordinate clause and the preceding utterance. The functionally extended subordinate clauses provide a background or a detailed explanation for the prior utterance without advancing the storyline. Moreover, Cristofaro (2016) summarized the viewpoints of Evans (2007) and Mithun (2008). He declared that the insubordinate clauses could be developed through a broader range of mechanisms than assumed. Many insubordinate clauses were compatible with different developmental mechanisms and source constructions. He proposed a new routine leading to insubordination, which he called clausal disengagement. Insubordinate clauses formed through this mechanism introduce a new topic related to a shared background between the speaker and hearer or elaborate on a topic introduced earlier in the conversation (Cristofaro, 2016, p. 6).

Those studies showed different viewpoints of the discourse functions and the forming mechanisms, and they apparently did not come with an agreement with one another. More studies with more language data, especially those that have not been discussed in previous typology studies yet, are necessary to verify and complement those viewpoints. Due to that, this paper will investigate the discourse functions of the insubordinate conditional clauses formed by - $b a$ in Japanese to verify and complement Evans' (2007) viewpoint.

$-B a$ is a conditional conjunction that connects with an apodosis to make a complex conditional sentence. It often forms insubordinate clauses in spoken Japanese to express the speaker's emotions and attitudes. Some researchers of Japanese linguistics studied the insubordinate -ba-clauses. Shirakawa (2009) used the term iisashi-bun, which means a sentence ending halfway, to describe them. Ohori $(1995,2002)$ raised the concept of suspended clauses, based on the concept of construction (Goldberg, 1995, 2006) to study them. Those studies provide materials for discussing the discourse functions and forming mechanisms. More details will be given in the chapter of "Literature Review".

This paper consists of the following sections. Section 2 is the literature review section, where more details of the previous studies of Japanese linguistic will be given. Section 3 is the central section, where I will discuss the discourse functions of insubordinate ba-clauses in detail. The investigation was carried out through the Balanced Corpus of Contemporary Written Japanese (BCCWJ). Besides the functions discussed in the previous Japanese linguistic studies, some new functions will also be discussed. Section 4 will clarify the differences between some discourse functions of the insubordinate - $b a$-clauses and the ones formed by the mechanism of dependency marker's functional extension, which was pointed out in Mithun (2008). Section 5 will discuss the interface between the two types of the discourse functions. In the last chapter, I will conclude this study and give some further issues. Section 3 verifies Evans' (2007) classification of discourse functions, and section 4 and section 5 complement that classification.

In the investigation of $\mathrm{BCCWJ}$, the insubordinate -ba-clauses mainly appeared as two forms: $[\mathrm{P}+\mathrm{V}-b a$ ?] and $[\mathrm{P}+\mathrm{V}-b a \ldots .$.$] .$ Hyphen indicates that $-b a$ must be used as a suffix after a verb or an adjective, despite being treated as a conjunction in Japanese linguistics. The form of $[P+V-b a$ ? $]$ corresponds with an interrogative intonation in spoken Japanese. However, the form of $[\mathrm{P}+\mathrm{V}-b a \ldots .$.$] may indicate either a declarative intonation or an interrogative intonation in spoken Japanese, because$ written Japanese does not obligatorily use a question mark to indicate an interrogative intonation.

\section{Literature Review}

Shirakawa (2009) defines the independently used -ba-clauses as iisashi-bun, which means sentences ending halfway. He assumes that iisashi-bun should be placed in the same position as the typical complete sentences. Three discourse functions were summarized, which are susume "recommendation", ganbō "wishes" and kigu "worry". Ganbō "wishes" expresses the speaker's desires to realize the conditional clause, and the kigu "worry" expresses the speaker's worry about that realization. Both two functions are a kind of epistemic modalities that expresses the speaker's positive or negative evaluation. Differing from the other two functions, susume "recommendation" is closer to be a deontic modality. It was also mentioned by Kato (2014) as "suggestion or recommendation" (ib., p. 17). (1) and (2) respectively shows the function of ganbō "wishes" and susume "recommendation". 


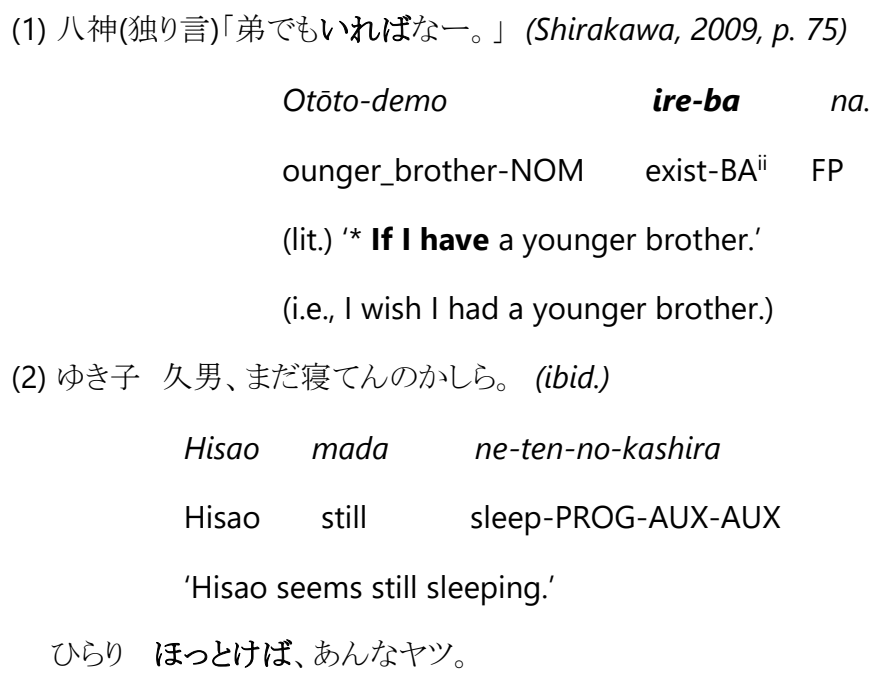
Hot-toke-ba
anna-yatsu
let_go-AUX-BA that_kind-person
(lit.) '* If let him alone. (He is) such a guy.'
(i.e., Just let him alone. He is such a guy.)

Ohori $(1995,2002)$ raised the concept of suspended clauses to analyze insubordinate clauses. Suspended clauses are a kind of construction (Goldberg, 1995, 2006) because they have conventionally combined the form of subordinate clauses with limited discourse functions. Ohori treated the insubordinate -ba-clauses as idiom-fragments of some fixed structures. For example, (3) is the fragment that represents the complex structure -ba ii "(that is) great if...".

(3) A: doo.si.te.mo ryuugaku-si.tai-n.desu.

by.all.means study.aboard-do-VOL-PRED

'I want to study aboard by all means.'

B: Zya sure-ba. (Ohori, 1995, p. 203)

Then do-BA

'Then, please.'

Ohori's viewpoint differs from Shirakawa's (2009) because he does not see insubordinate -ba-clauses as independent constructions. That means the insubordinate - ba-clauses do not endorse their discourse functions themselves. Instead, they must obey the functions of the original complex structures. Although Ohori raised the concept of suspended clauses, by which he should treat -ba-clauses as independent constructions, his main concern was not -ba-clauses. His main concern was the insubordinate clauses that typically bear an independent logical connective, such as the causative conjunction kara "because". He almost did not give any more arguments about -ba-clauses than giving the example of (3).

Kato's (2014) mentioned about -ba-clauses when discussing the phenomenon of additional insubordination. Additional insubordination is a phenomenon that a complete sentence turns into an insubordinate clause by being added come element at the end. For example, an incomplete noun can be added at the end of a complete sentence so that the sentence obtains the form of a subordinate clause and endorse new discourse functions. He treated the concept of insubordination raised by Evans (2007) as elliptic insubordination, and he gave the examples of -ba-clauses, pointing out two discourse functions, which are recommendation or suggestion, and expressing counterfactual desire. He also argued that the function of recommendation or suggestion was formed with an interrogative intonation. Although he mentioned -ba-clauses in his discussion, he did not point out anything more unique than other previous studies.

To summarize, previous studies have discovered some discourse functions of the insubordinate -ba-clauses, which can be organized as wishes, worry and recommendation (or suggestion). However, as will be discussed, those discourse functions do 
not cover all the functions that insubordinate - ba-clauses have. The next chapter will argue more discourse functions that were not discuss in the previous studies.

\section{Classification of discourse functions}

Evans (2007, pp. 386-410) classified the functions of insubordinate clauses towards a typology perspective. His classification includes various language and source constructions, not only conditional clauses. The classification is as follows.

[1] Indirection and interpersonal control:

Ellipsis predicates of desires, ellipsed enabling predicate, ellipsed result clauses, free-standing infinitives, warnings and admonitions, Insubordinate request and politeness

[2] Modal insubordination:

Epistemic and evidential meanings, deontic meanings, exclamation and evaluation, new tense categories through deictic recentering

[3] Signaling presupposed material

Negation, contrastive focus constructions, trans-sentential contrast and switch- reference, conditions on preceding assertions in interaction, reiteration, disagreement with assertions by the previous speaker

Since this classification includes not only the insubordinate clauses that are formed by adverbial clauses (such as conditional clauses and causative clauses) but also those that are formed by other source constructions (such as subordinate word order and embedded clause), it may not completely fit the conditional clauses. For example, the classifications of [1] and [2] are not necessary in the situation of conditional clauses, as shown in (4) and (5).

(4) Oishasan ni it-tara? (Evans, 2007, p. 390)

doctor LOC go-COND

(lit.) '* If you go to see a doctor?' (i.e., I suggest you go to see a doctor.)

(5) Okay if you'd like to get dressed now. (Stirling, 1999, p. 273)

(4) is an insubordinate conditional clause formed by Japanese conditional connective -tara. It indicates a recommendation to the listener. (5) is an insubordinate conditional clause formed by conditional connective if. It indicates an indirect request, which means "I want you to get dressed now". Both examples are naturally to be explained as the ellipsis of result clauses expressing good results, such as "that would be good" and "I would be happy". Therefore, they are naturally treated as the subtype of [1], "ellipsed result clauses". However, simultaneously, both (4) and (5) express deontic meanings, encouraging the listener to take some action. Some researchers also noticed this issue. For example, Shirakawa (2009, p. 171) argued that the function shown in (4), in other words, the function of susume "recommendation", could be positioned to deontic modality. Therefore, the two examples should also be treated as the subtype of [2], "deontic meanings".

Due to the arguments above, I adjusted Evans' (2007) classification based on the investigation result of the insubordinate -baclauses. The type of [1], "indirection and interpersonal control" was treated as a subtype of [2], "deontic meanings". The type of [3], "signaling presupposed material", was retained, but a new subtype, "requirement of further information", was added to it. The adjusted classification is shown as follows.

Type A: Modal insubordination

A-1: Epistemic and evidential meanings

A-2: Deontic meanings

Type B: Signaling presupposed material

B-1: Disagreement with assertions by the previous speaker

B-2: Requirement of further information 
Although the subtype B-2 is a newly added function, as will be discussed below, it is closely related to the existing subtype "disagreement with assertions by the previous speaker". The function of B-2 is a complement to Evans' (2007) classification. Type A functions were mentioned by Shirakawa (2009) as susume "recommendation", banbō "wishes" and kigu "worry". However, Type B functions have not been discussed by previous Japanese linguistic studies yet. iii Therefore, Type B functions complement the blanks of Japanese studies.

\subsection{Type A: Modal insubordination}

Type A has two subtypes: A-1, "epistemic and evidential meanings", and A-2, "deontic meanings". Subtype A-1 shows either the speaker's emotion of wishes or worry towards the realization of the -ba-clause. (6) and (7) are examples showing the speaker's wishes.

(6)一日でも早く、雪が降れば... (Shinoda Mayumi: Dorakyurakou)

Ichinichi-demo-haya-ku yuki-ga hure-ba

one_day-FOC-early snow-NOM fall-BA

(lit.) 'If it snows one day earlier... (things would be better)'

(i.e., I wish it would snow one day earlier.)

\section{(7)この辺の経緯を知っている者がいれば...。 (Orihara Ichi: Ijintati No Kan)}

Konohen-no-keii-wo shit-teiru-mono-ga-ire-ba

around_here-GEN-circumstance-ACC know-PROG-person-NOM-exist-BA

(lit.) 'If there is someone knowing about the circumstances around here...(that would be helpful)'

(i.e., I wish someone knew the circumstances here.)

In the -ba-clauses indicating wishes, main clauses expressing the speaker's positive evaluation can be added, such as iina "so good" and ureshii "(I feel) happy". The addable main clauses are limited to restricted meanings, which makes them satisfy the third step of the historical trajectory leading to insubordination ("the restoration of material is conventionalized to a subset of the grammatically tolerated possibilities" (Evans, 2007, p. 372). That is the same with the "if-request" constructions in English, in which the addable main clauses are restricted towards a positive consequence rather than a negative one.

(8) If you could give me a couple of 39c stamps please, (l'd be most grateful) (id., p. 380)

Although some main clauses can be added, they are not necessary for forming of the function of worry. Instead, the constituent elements inside the -ba-clause implicating positive emotions guarantee the formation of that function, such as ichinichi demo hayaku "one day earlier" in (6) and keii wo shitteiru "know about the circumstance" in (7).

(9) and (10) indicate the speaker's worry of the realization of the -ba-clauses. Main clauses expressing the speaker's negative evaluation can be added, such as taihenda "(that is) tough" and mazuiyo "(that is) terrible". However, they are not necessary for forming the function of worry either, the same as the function of wishes.

(9) おまけに、チェルノブイリ原発や

Omakeni, cherunobuirigenpatsu-ya

besides Chernobyl_Nuclear_Disaster-and

スリー・マイル島原発のような事故が、

surīmairujimagenpatsu-no-yōna-jiko-ga,

Three_Mile_Island_NuclearDisaster-GEN-like-disaster-NOM

狭い日本で起これば…、と思うと、

semai-nihon-de okore-ba ... to-omou-to, 
narrow-Japan-LOC happen-BA QT-think_of-CONN

多くの人は不安になる。(Ishiguro Akaru: Shinsairettō)

ōkuno-hito-ha fuan-ni-naru.

many-people-TOP anxious-RES-become

'Besides, if a disaster like the Chernobyl Nuclear Disaster and the Three Mile Island Nuclear Disaster happens in this narrow Japan... (things would get out of hand) Many people get anxious when thinking of that.'

(10) 石油の需要のほとんど百パーセントといっていいくらいを、

sekiyu-no-juyō-no hotondo-hyakupāsento-to-itte-ii-kurai wo,

petroleum-GEN-need-GEN mostly-100\%-QT-say-good-about ACC

外国に依存しています。石油が枯渇すれば... (Uchida Yasuo: Kaidan No Michi)

gaikoku-ni izon-shi-tei-masu. Sekiyu-ga kokatsu-sure-ba...

foreign_country rely-AUX-PROG-AUX petroleum-NOM run_out-AUX-BA

'(We) can mostly say that about $100 \%$ of Japan's petroleum need relies on foreign countries. If the petroleum runs out... (things will be out of control)'

The -ba-clauses endorsing the function of worry also satisfy the features of the third step of the historical trajectory leading to insubordination (Evans, 2007). The grammatically addable main clauses are restricted to limited meanings that express the speaker's negative evaluation.

However, they were not widely found as the function of wishes in the investigation. Shirakawa (2009) argued that -ba-clauses cannot form the function of worry because of its semantic mechanism. Although this viewpoint is too absolute, it suggests the limitation of -ba-clauses to the form the function of worry. In fact, Japanese native speakers prefer to use another conditional connective, -tara, to make the same function.

\section{(11) こんな中で爆発があったら...。(Ōishi Naoki: Bakudanma)

Konnanaka-de bakuhatsu-ga at-tara... \\ such_situation-LOC explosion-NOM happen-TARA}

(lit.) 'If an explosion happens in such a situation...(things would be out of control)'

(i.e., I'm worried that an explosion happens in such a situation.)

Differing from subtype A-1, subtype A-2, "deontic meanings", expresses the speaker's directive attitude to the listener. It indicates a recommendation or suggestion. The -ba-clauses occur with an interrogative intonation, as shown in Kato (2014). Additionally, they need to satisfy the condition that the subject is the listener, and the predicate is a volitional action (Shirakawa, 2009).
(12)「パパは行けば?
Papa-ha ike-ba?
dad-TOP go-BA
わたしは、レイチェルと一緒に教会に行くから」
Watashi-ha, Reicheru-to issyoni kyōkai-ni iku kara.
I-TOP Rachel-COM together church-ALL go CONN.because

(Karine Sally: Natsuiro No Maashii, translated by Kirinou Asuka) 
(lit.) '* Dad, if you go? Because I will go to church with Rachel.'

(i.e., Dad, why don't you go? I will go to church with Rachel.)

(13)「訊きたいことがあれば、訊けば?」(Konnobin: ST Ao No Tyōsafairu)

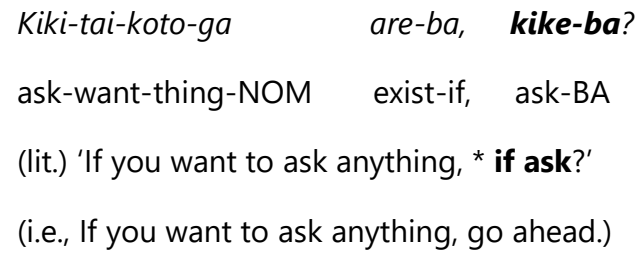

-Ba-clauses endorsing this function can also connect with some main clauses, whose meanings are limited to ask for the listener's evaluation of the conditional clause, such as dō "what do you think" and iinjanai? "isn't it good?". However, those main clauses are not necessary to form the discourse function. Instead, the state of the constituent elements that the subject is the listener, and the predicate is a volitional action guarantee the formation of that discourse function.

Subtype A-1 and subtype A-2 and relate to each other in that one shows the speaker's evaluation and the other asks for the listener's. Furthermore, the two discourse functions of subtype A-1 contrast with each other in that one shows the speaker's positive evaluation and the other shows negative one. The evaluations towards the conditional clauses are directly shown or indirectly implicated by the constituent elements inside the -ba-clauses.

Those evaluations are decided by the speaker or the listener's subjective feelings. Therefore, there may be an evaluative gap between the interlocutors. For example, in (14), the speaker provides the -ba-clause as an expected proposal, but the listener thought it to be unexpected.

(14)「いいじゃない。面白そうだし。やってみれば?」

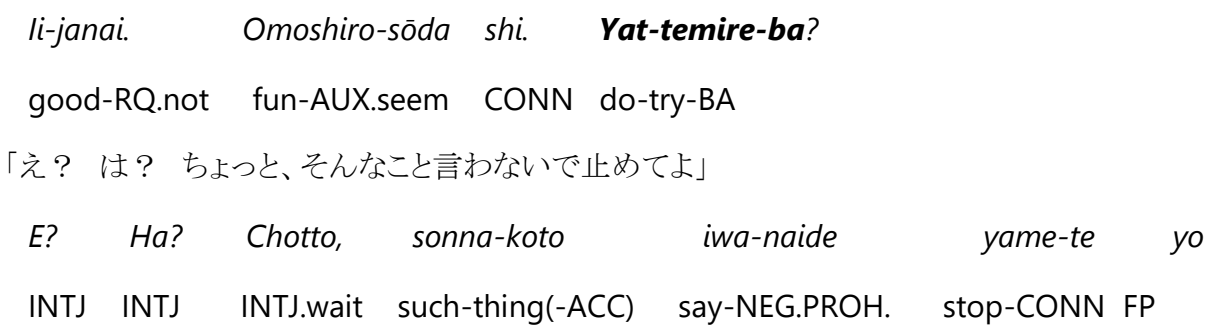

(Tomono Tsumabiraka: Naraku Ni Tokimeku Bōkensha)

'Isn't it good? Sounds interesting. (How about) if you do it?'

'What? Excuse me? Wait a minute. Don't say that again.'

\subsection{Type B: Signaling presupposed material}

Type B also has two subtypes: B-1 "disagreement with assertions by the previous speaker" and B-2 "requirement of further information". Type B functions share a commonality that both are formed by the process of showing a contrastive condition. Subtype B-1 shows the speaker's disagreement to the prior utterance, as shown in (15) and (16).

(15)「おまえの記録を残すのは勝手だ。

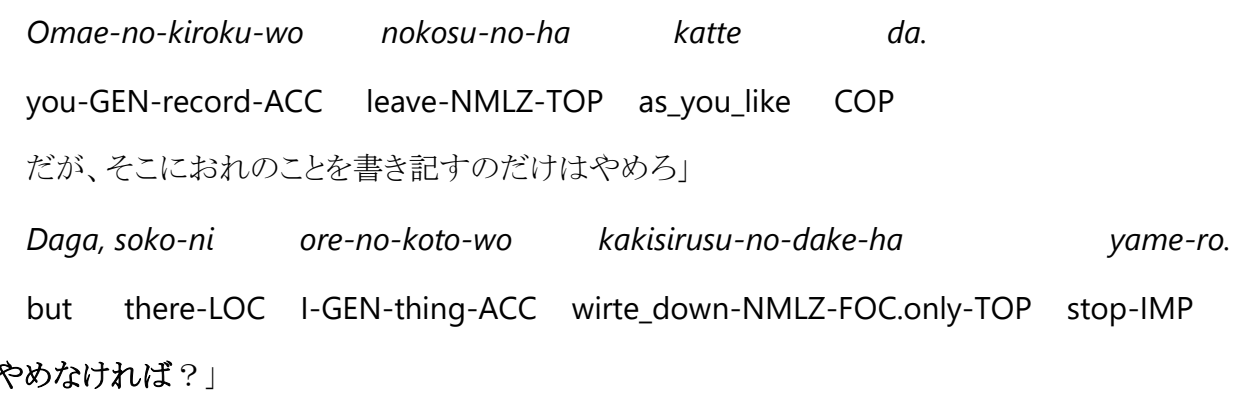




\section{Yame-nakere-ba?}

stop-NEG-BA

(The middle part was omitted.)

「日本人の刀で斬り殺される前に、

Nihonjin-no-katana-de kirikoros-areru-maeni,

Japanese_people-GEN-sword-INS kill-PASS-NMLZ.before

おれがおまえをひねりつぶしてやるさ」

ore-ga omae-wo hineritsubusi-teyaru sa

I-NOM you-ACC pinch_out-BEN FP

「本気?」

Honki?

serious

「本気だ」(Yoshimura tatsuya: 'Yokohama No kaze' Satsujinjiken)

Honki da.

Serious COP

'You can leave your record as you like, but don't write down mine there.'

(lit.) ‘* If I don't stop?' (i.e., I don't want to stop.)

'(If so) I will pinch you out before (someone) kills you in a Japanese sword.'

'Are you serious?'

'Yes, I am.'

(16)「逃げ道になるもんですか。

Nigemichi-ni naru-mon $\quad$ desu.

escape_route-RES become-NMLZ AUX.judgment Q

こんなところへ落ちたら、完璧に死んじゃう」

Konna-tokoro-he ochi-tara, kanpekini shin-jau.

such-place-ALL fall-CONN.if perfectly die-AUX.completion

「だれが逃げ道といいました? 俺は出口といったんです。

Dare-ga nigemichi-to ii-masi-ta? Ore-ha deguchi-to itta-n-desu.

who-NOM escape-QT say-AUX-PAST I-TOP exit-QT say-NOLZ-AUX.judgement

…たまたま俺たちは、風早が壁落したのを見た。

... Tamatama ore-tati-ha, Kazehaya-ga tsuirakusi-ta-no-wo mi-ta.

by_chance I-PL-TOP Kazehaya.name-NOM fall-PAST-NMLZ-ACC see-PAST

だがその直前に、犯人もまた墜落したのだとすれば?」 


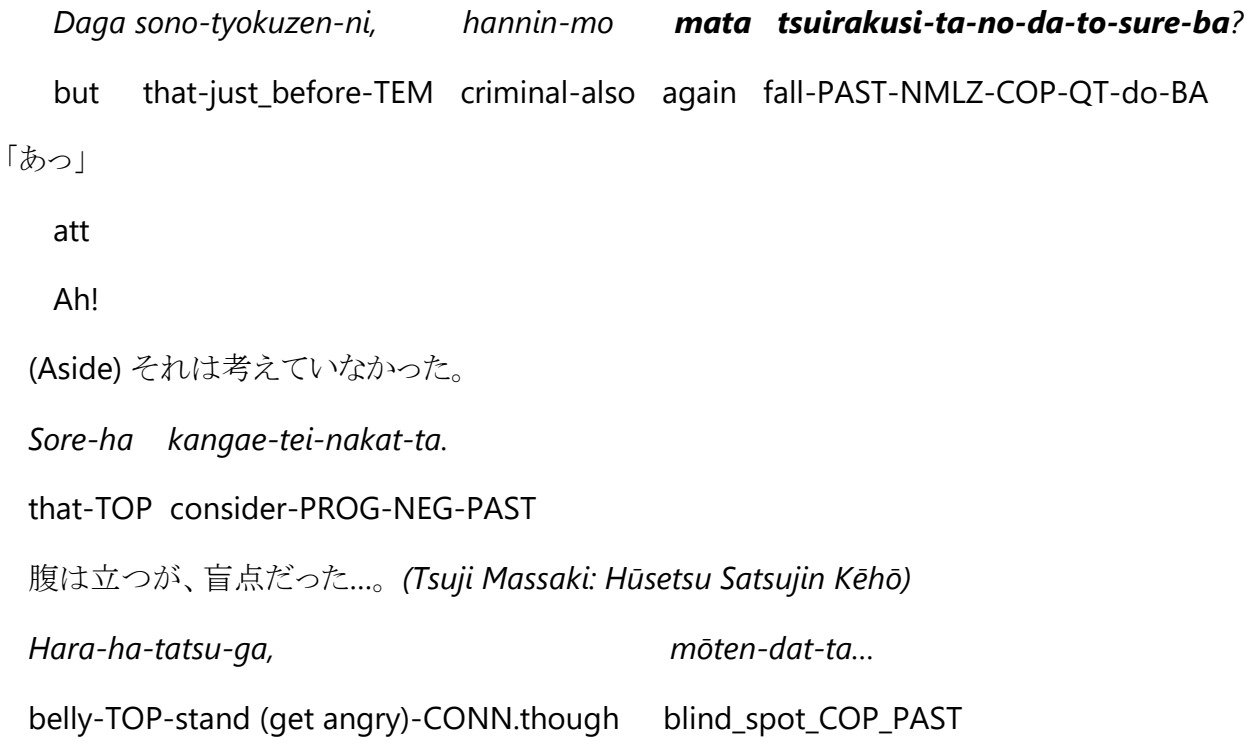

A contradictory conjunction, such as demo "but" and shikashi "however" can be put before the -ba-clauses. The contrastive meaning can naturally be read from the relation between the prior utterance and the -ba-clauses. Also, the speaker's defiant emotions, such as anger and surprise, are often shown in the context. The -ba-clauses can also connect with some main clauses which are restricted to limited meanings. Those main clauses literally ask the result of the conditional clause or the action to deal with that result, such as dōnaru? "what will happen?" and dōsuru? "what will you / should I do?". However, these main clauses have already lost their literal meanings. They function to express the speaker's doubt, complaints, and hopelessness. Their pragmatic meanings are almost the same with "there is nothing I can". The added main clauses have obtained generalized conversational implicatures (GCl) $(\mathrm{Grice}, 1975)$ and are used to indicate indirect speech acts (Searle, 1975).

Differing from subtype B-1, subtype B-2, "requirement of further information", does not show disagreement but only requires further information related to the prior utterance, as shown in (17).

(17) そして、入院五日後の二十日日曜、

Soshite, nyūin-gonichi-go-no

and, hospitalize-five_days-after-GEN

茂の妻真理子から、衝撃の電話を受ける。

Shigeru-no tsuma-Mariko kara, shōgeki-no denwa-wo ukeru.

Shigeru.name-GEN wife-Mariko.name from shock-GEN call-ACC receive

前日、病棟の担当医Kさんに会ったところ、

Zenjitsu, byōtō-no tantōi-K-san-ni at-ta-tokoro,

The_day_before hospital-GEN physician-K-Mr-ACC meet-PAST-NMLZ

『肝臓のかなりの範囲に癌の転移が見られ、

"Kanzō-no-kanari-no-hani-ni gan-no-teni-ga mi-rare, hatsuka-nichiyō,

20th-Sunday 
liver-GEN-quite-GEN-scope-LOC cancer-GEN- metastasis-NOM see-PAST

手術しても一年持つかどうかわからない』と言われたとのこと。

Shujutsusi-temo ichinen-motsu kadōka wakara-nai"-to iw-are-ta-to-no-koto.

operate-even_if one_year-last Q.if know-NEG-QT say-PASS-PAST-QT-GEN-NMLZ

「じゃあ、手術しなければ?」と、私は聞いた。

"Jā, shujutsusi-nakere-ba?" to, watasi-ha kii-ta.

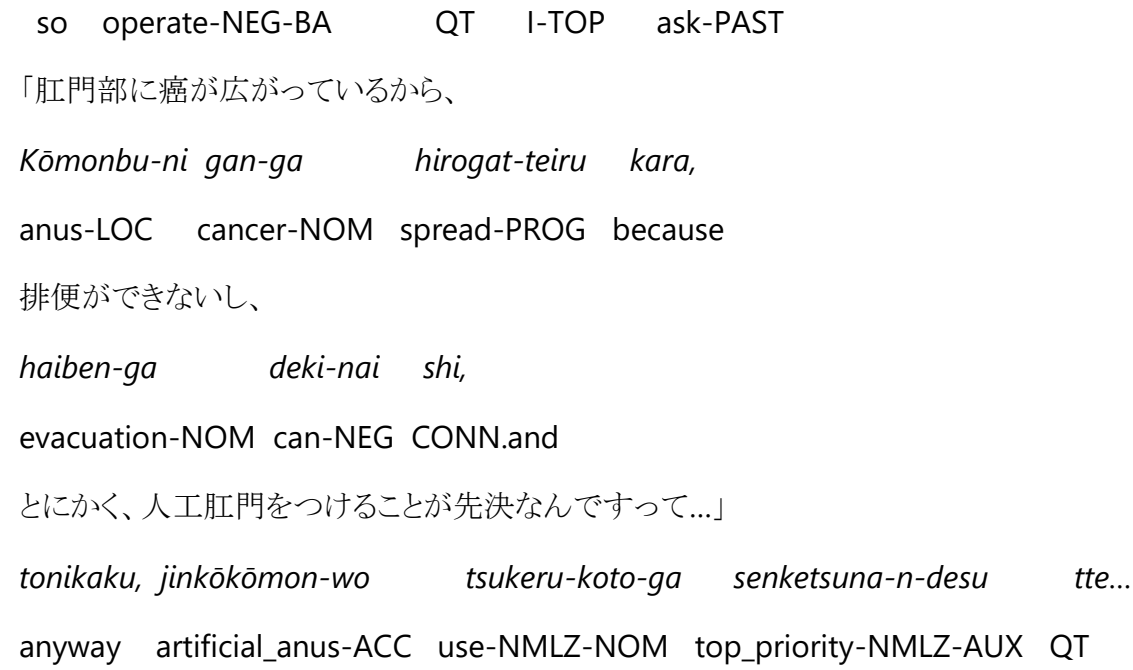

(Sano Yō: Minareta Kēshiki Ga Kawaru Toki)

'Then, on Sunday, the 20th, five days after (Shigeru's) hospitalization, I received a call from Shigeru's wife, which shocked me. She said she went to see Dr. K a few days ago and heard this: "Cancer spread to quite (wide) range in his liver. His life may not last for (more than) one year even if (I) make an operation." I asked: "So, (what will happen) if (you) don't make the operation?" (She answered) the doctor told her: "Since cancer has spread to his anus, he can't evacuate now. Anyway, we should install him the artificial anus first."'

The speaker does not disagree with the doctor's opinion but ask for further information related to that opinion. Although the $b a$-clause provides a contrastive condition, that condition shows the speaker's further concerns for the prior opinion. - $B a$-clauses endorsing B-2 function can connect with main clauses that are constrained to the meanings of asking the result of the conditional clauses or the action to deal with that result, such as dōnaru? "what will happen?" or dōsuru? "what will you/should I do?". However, they differ from subtype B-1 in that they do not express any pragmatic meanings showing the speaker's defiant attitudes. The speaker only intends to provide a contrastive condition as a further related situation to the prior utterance and asks about its result.

Shirakawa (2009, p. 74) did not treated subtype B-2 as insubordinate clauses, because he assumed that the listener cannot grasp the meanings of these sentences without speculating the omitted main clause (id., p. 75). He gave the example of (18).

(18) みゆき:入試に落ちたら?

Miyuki: Nyūshi-ni ochi-tara?

Miyuki.name entrance_exam-ACC fall-TARA

宏:就職するよ。(Shirakawa, 2009, p. 74)

Hiro: Shūshokusuru yo.

Hiro.name find_a_job FP

'Miyuki: (What will you do) if you fall the entrance exam?' 
'Hiro: I will find a job.'

Despite Shirakawa's viewpoint, I treat those conditional clauses as insubordinate clauses. The main clauses of (16), (17) and (18) have been conventionalized to limited meanings that indicate requirements of the results of the conditional clauses or the actions to deal with those results. The -ba-clauses can be considered as the products of the third step of the routine leading to insubordination (Evans, 2007). The listener takes little effort to speculate the main clauses.

The forming mechanisms of Type A functions and Type B functions differ from each other in that how they rely on the preceding utterance to form discourse functions. For Type A, the discourse functions form themselves based on the constituent elements inside the conditional clauses that indicate the speaker's positive or negative evaluations, and the special features of the subject and predicate, the subject being the listener and the predicate being a volitional action. The preceding utterance plays the role to provide a natural flow of the conversation for the speaker's presenting that discourse function. For example, in (19), the -baclause has already formed the function of wishes based on the internal constituent elements norikiru "overcome" and kotogadekiru "can". The preceding context only provides a background for the speaker's expressing his/her wishes, rather than form that discourse function. The same situation happens in (20) that indicates the function of worry. The internal constituent elements of tondemonai "unbelievable (because it is too terrible)" and konname "such a (terrible) situation" have already guaranteed the function of worry. No preceding context is needed to form that function.

(19) フライトはあすの朝のニューヨーク行きコンコルドを予約した。

Furaito-ha asu-no-asa-no Nyūyōku-yuki-Konkorudo-wo yoyakushi-ta.

Flight-TOP tomorrow-GEN-morning-GEN New_York-going-Concord-ACC reserve-PAST

あと数時間、無事に乗りきることができれば...。

Ato-sūjikan, bujini norikiru-koto-ga dekire-ba....

remained-a_few_hours peacefully overcome-NMLZ-NOM can-BA

(Baird Jacqueline: Futari No Barentain, translated by Haruno Hiroko)

'I reserved the Concord flight flying to New York tomorrow morning.

(lit.) * If I can overcome the next few hours safely...

(i.e., I hope I could overcome the next few hours safely)'

(20)「とんでもない。誰だって、こんな目にあえば...」(Shindō Fuyuki: Dobunezumi)

"Tondemonai. Dare-datte, konname-ni ae-ba..."

unbelievable who-no_matter such_thing-ACC suffer-BA

'Don't mention it!

(lit.) Whoever, * if suffers like that...

(i.e.) Nobody hopes to suffer like that.'

In contrast, Type B functions must rely on the preceding utterance to form themselves. That is because their formation is based on the process of providing a contrastive condition to the preceding utterance. The functions of showing disagreement to the preceding utterance and indicating requirement of further information related to the preceding utterance cannot be formed without the preceding utterance existing.

Furthermore, the ba-clauses endorsing Type B functions not only include the process of showing contrastive conditions, but also the process of literally asking the results of the - $b a$-clauses or the actions to deal with those results. As shown from addable main clauses with the restricted meanings of "what will happen" and "what will you/should I do", the -ba-clauses can realize the latter process by themselves. However, they cannot realize the former process by themselves because they do not mark the - $b a-$ clauses as contrastive conditions by themselves. At the point when the speaker shows a -ba-clauses as a contrastive condition, he/she has already taken the preceding utterance into consideration. The preceding utterance is inevitably essential for the formation of Type B functions. 


\section{Differences from Mithun's (2008) functional extension}

Type B functions shows a pragmatic connection, which is a contrastive relation, with the preceding utterance. That makes it appear to be same to the mechanism of the dependency markers' functional extension that was pointed out by Mithun (2008). The dependency marker = go in Navajo was given as an example in Mithun (2008). The enclitic = go initially marks adverbial clauses and some complement clauses, meaning "when/while/after" or "if/although". The subordinate clauses formed by = go syntactically subordinate to the matrix clauses and do not constitute independent sentences on themselves (id., p. 70). However, in many cases, = go extends its function to a larger range. It turns to mark the subordinating relation between the subordinate clauses and the adjacent discourse paragraphs. Those functionally extended = go clauses function to provide background information, explanation, or commentary to the adjacent discourse, as shown in (21).

$$
\begin{aligned}
& \text { (21) Ndee ei nashdoitsoh akoo ch'eelwodla. } \\
& \text { nidee ei nashdoi }=\text { tsoh } \quad \text { akoo ch'ee-ø-1-wod=la } \\
& \text { then that } \quad \text { wildcat }=\text { big } \quad \text { thither out.horizontally-3.SUBJ-CL-run=MIR }
\end{aligned}
$$

'That mountain lion ran.

$$
\begin{aligned}
& \text { Ei shii leechaa'l shii beejilzido. } \\
& \text { ei shii leechaa'=i shii bi-na-ji-1-zid=go (id., p. 82) } \\
& \text { that probably dog }=\mathrm{NMZ} \text { probably 3-about-4.SUBJ-CL-fear.PRF = DEP } \\
& \text { that probably dog probably it was afraid of them }
\end{aligned}
$$

I guess it was afraid of the dogs. ${ }^{\text {iv }}$

Those independent $=$ go clauses also show a pragmatic connection with the preceding context, in that they complement additional information to it. However, they are not the same with the -ba-clauses endorsing Type B functions. One of difference is shown by their functions. Mithun (2008, p. 70) argued that the independent = go clauses did not advance the storyline. They only complement some additional information without pushing forward the flow of the conversation. In contrast, the -ba-clauses endorsing Type B functions advance the storyline positively in that they show disagreement or request further information towards the preceding utterance.

The other difference is reflected in the addable main clauses. As discussed, -ba-clauses of Type B can naturally connect with main clauses that are limited to the meanings of "what will happen?" and "what will you / should I do?". However, the independent = go clauses cannot connect with any main clauses in the presupposition of not changing their functions, because their main clauses still exist, despite in new forms. The main clauses did not disappear but were changed from the forms of specific matrixes to larger units, the adjacent discourse paragraphs. The functions of = go clauses did not change. They still function to provide background information as initially did as subordinate clauses. That difference comes from the forming mechanisms of the two different types of insubordinate clauses. For the insubordinate -ba-clauses, they have abandoned the main clauses and been reanalyzed as new constructions. They do not subordinate to a matrix clause anymore. However, the independent $=g o$ clauses have not abandoned their main clauses. The main clauses were changed to another form. Therefore, the independent $=$ go clauses still subordinate to the main clauses, although the "main clauses" were change to a different pattern.

\section{Interface-looking function between Type A and Type B}

The forming mechanism of Type A functions can be summarized as the speaker's expressing evaluation towards the conditional clauses. Positive evaluation leads to the function of wishes, and negative evaluation leads to the function of worry. Moreover, the speaker's requiring the listener's evaluation leads to the function of recommendation. As to Type B functions, their forming mechanism can be summarized as the speaker's providing a contrastive condition and requiring the listener's response. The addable main clauses whose meaning are limited to "what will happen?" or "what will you / should I do?" literally show the speaker's asking the results of the conditional clause and the actions to deal with those results. They may also express the speaker's complaints and doubts in appropriate context, promoting the speaker's disagreements to the prior utterance.

Type A and Type B distinguish each other apparently in most cases. Structurally, Type A functions are presented as declarative sentences (except the function of recommendation), and Type $B$ functions are represented as interrogative sentences. That corresponds to their addable main clauses, in which Type A declares the speaker's evaluations, and Type B asks results and actions. However, there exist an interface-looking function between these two types, the function of worry. As a subtype function of Type A, the function of worry conventionally omits main clauses declaring the speaker's negative evaluation, such as taihen da 
"so tough" and mazui "so terrible". They omitted main clauses are mostly declarative sentences. However, Japanese native speakers also use another expression to show their worry, which is dō shi yō "what should we/l do". Dō shi yō "what should we/l do" literally asks the action to deal with some result. However, they are conventionalized to express the speaker's worry as a rhetorical question. Therefore, they can naturally connect with the -ba-clauses endorsing the function of worry, as shown in (22).

$$
\begin{array}{ccc}
\text { (22) (= 10) 石油が枯渴すれば どうしよう。 } & \\
\text { Sekiyu-ga } & \text { kokatsu-sure-ba } & \text { dōshi-yō } \\
\text { petroleum-NOM } & \text { run_out-AUX-BA } & \text { what_to_do-VOL }
\end{array}
$$

(lit.) 'If the petroleum runs out, what can we do?'

(i.e., If the petroleum runs out, we can't do anything.)

The literal meaning of dō shi yō "what should we/l do" seems to make the -ba-clauses endorsing the function of worry possess some features of Type B functions. However, despite its structure, its function is closer to an interrogative sentence, such as "I can't do anything", showing the speaker's hopelessness and disappointment. Therefore, dō shi yō "what should we/l do" should functionally be treated as a declarative sentence rather than an interrogative sentence. That suggests an evident criterion to classify Type A and Type B functions. The structurally declarative sentences and interrogative sentences are not enough. More concerns should be paid to a functional perspective.

Additionally, Type B functions can also also indicate the speaker's worry in some cases, as shown in (23).
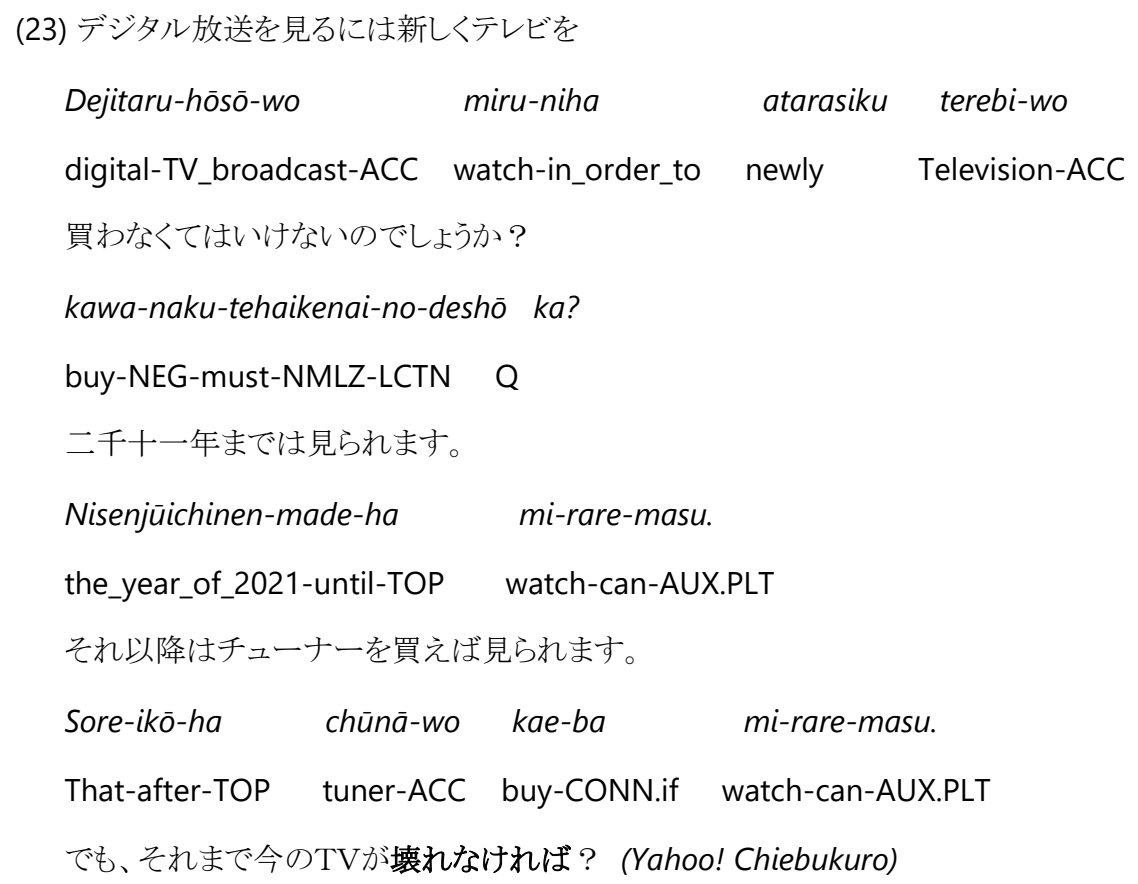

Demo, sore-made ima-no-TV-ga koware-nakere-ba?

but that-until this-GEN-TV-NOM break-NEG-BA

'Do I need to buy a new TV to watch the digital TV broadcast? (The new TV) can be used until the year 2011, and then I should buy a tuner to watch (the digital TV broadcast).

(lit.) * But if the TV isn't broken then?'

(i.e., I'm worried that the TV wouldn't be broken then.)

(23) shows the speaker's disagreement to the prior utterance. The prior utterance shows a presupposition that the TV can only be used until the year 2011. To resist that opinion, the speaker provides ancontrastive condition that the TV will not be broken before that year. The -ba-clause can also be explained to be indicating the speaker's worry. The speaker not only shows 
disagreement but also worries about the realization of the -ba-clauses. The function of worry is a secondary function of the function of disagreement. It is a particularized conversational implicature (PCI) (Grice, 1975) of the -ba-clause.

To summarize, although the function of worry can occur in both Type A and Type $B$, it is formed in totally different mechanism in each type. In Type $A$, the addable main clauses still function as declarative sentences, despite structurally presented as interrogative sentences. The function of worry does not change its characteristics as a Type A function. Whereas, in Type $B$, the function of worry is only a $\mathrm{PCl}$ of the -ba-clauses endorsing the function of disagreement. The - ba-clauses do not change their characteristics as conditional clauses endorsing Type B functions. The different forming mechanisms make the function of worry difficult to connect the functions of Type A and Type B. However, it suggests an apparent distinction between Type A and Type B. The distinction is based on a functional perspective rather than a structural perspective.

\section{Conclusion}

This paper discussed the discourse functions of the insubordinate conditional clauses formed by Japanese conjunction -ba. I referred to Evans' (2007) classification and adjusted it according to the investigation of the insubordinate -ba-clauses that was done through the Balanced Corpus of Contemporary Written Japanese (BCCWJ). The adjusted classification helpd find more discourse functions in - $b a$-clauses, especially those not mentioned by previous Japanese studies. I also discussed the differences between the -ba-clauses endorsing Type B functions and the independent =go clauses discussed by Mithun (2008). Also, the interface-looking function of Type A and Type B was discussed.

Evans (2007) classified the discourse functions of insubordinate clauses into three types in a typology perspective: [1] Indirection and interpersonal control, [2] Modal insubordination, [3] Signaling presupposed material. That classification covers various languages and source constructions, causing it not able to fit - ba-clauses directly. Due to that, I adjusted that classification slightly, but kept Evans' (2007) main viewpoint. The newly adjusted classification fits -ba-clauses well and complements some functions that were not discussed in the previous Japanese linguistic studies. The -ba-clauses endorsing Type B functions show some similarities with the independent $=$ go clauses discussed by Mithun (2008). However, they indeed differ from each other in their functions and forming mechanisms. That also clarifies the distinction of the viewpoints of Evans (2007) and Mithun (2008). The function of worry can occur in both Type A and Type B, making it seem to be an interface function. However, it is formed in totally different mechanisms in these two types, making it impossible to connect Type $A$ and Type B. That suggests an apparent distinction to Type A functions and Type B function, as well as to the type of [3] signaling presupposed material with the other two types in Evans (2007).

I conclude that Evans' (2007) classification fits -ba-clauses as well, despite with a slight adjustment. A new discourse function "requirement of further information" was added, but it closely relates to the existing function "disagreement with assertions by the previous speaker". The newly added function does not resist Evans' (2007) viewpoint but complement it.

Evans' (2007) classification helps construct the classification of conditional clauses towards a typology perspective. To construct the classification of conditional clauses, investigation and discussion about more language data are necessary. This paper discussed the -ba-clauses. However, as mentioned, some other conditional connectives in Japanese can also form insubordinate clauses. To study the discourse functions and the forming mechanisms of more conditional connectives in one language, moreover, in many languages, is a further issue. To solve that issue both previous studies of typology and individual languages are necessary to be referred. In return, the typology studies about conditional clauses can also contribute to both the studies of typology and individual language.

Funding: This research received no external funding.

Acknowledgments: I wish to thank my academic advisor, Professor Sakuma Junichi, Graduate School of Humanities, Nagoya University, for encouraging me to conduct this research. His encouragement made me feel more confident in myself. That was the beginning of this paper. I also want to thank the editor and the reviewers of the International Journal of Linguistics, Literature and Translation (IJLLT). I feel thankful for their time spent on this paper and their suggestions for improving it. Without the help from the people above, this study would not have been published as a paper.

Conflicts of Interest: The author declares no conflict of interest. 


\section{References}

[1] Cristofaro, S. (2016). Routes to insubordination: A cross-linguistic perspective. In N. Evans \& H. Watanabe (Eds.), Insubordination (pp. 393422). John Benjamins. https://doi.org/10.1075/tsl.115.15cri

[2] Evans, N. (2007). Insubordination and its uses. In I. Nikolaeva (Ed.), Finiteness: Theoretical and Empirical Foundations (pp. 366-431). Oxford University Press. https://bit.ly/3d2ewV7

[3] Evans, N. (2009). Methodologies in determining morphosyntactic change [Conference]. Ritsuko Kikusawa Museum of Ethnography, Osaka, Japan. https://bit.ly/3tO8Yna

[4] Kato, S. (2014). Insubordination types in Japanese: What facilitates them?. Asian and African Languages and Linguistics, 8, 9-30. https://bit.ly/3rME2Se

[5] Goldberg, A. E. (1995). Constructions: A Construction Grammar approach to argument structure. Chicago University Press. https://bit.ly/3d3VFsU

[6] Goldberg, A. E. (2006). Constructions at work: The nature of generalization in language. Oxford University Press. https://bit.ly/2MZfPcG

[7] Grice, H. P. (1975). Logic and conversation. In P. Cole, J. Morgan (Eds.), Syntax and Semantics 3: Speech Acts (pp. 41-58). Academic Press. Reprinted in Grice, H. P. (1989) (Ed.), Studies in the Way of Words (pp. 22-40). Harvard University Press.

[8] Jiang, J. (2020). Nicchū ryōgengo no fukushisetsu no hijūzokuka kōbun no gengokēshiki to danwakinō: Ninchiruikēron no kanten kara (the insubordinate constructions formed by adverbial clauses in Japanese and Chinese: a cognitive typology perspective). [Doctoral dissertation, Nagoya University]. Nagoya University. https://bit.ly/3pcFgVe

[9] Mithun, M. (2008). The extension of dependency beyond the sentence. Language 83, 69-119. https://bit.ly/3d3JlbS

[10] Ohori, T. (1995). Remarks on suspended clauses: a contribution to Japanese phraseology. In M. Shibatani \& S. A. Thompson (Eds.), Essays on Semantics and Pragmatics (pp. 201-218). John Benjamins. https://doi.org/10.1075/pbns.32.11oho

[11] Ohori, T. (2002). Ninchi gengogaku (Cognitive Linguistics). University of Tokyo Press. https://bit.ly/3d7bYVJ

[12] Shirakawa, H. (2009). Iisashibun no kenkyū (A study on Insubordinate clauses). Kuroshio Publishers. https://bit.ly/3rMQ2TM

[13] Searle, J. (1975). Indirect Speech Acts. In P. Cole \& J. L. Morgan (Eds.), Syntax and Semantics 3: Speech Acts (pp. 59-82). Academic Press.

[14] Stirling, L. (1999). Isolated if-clauses in Australian English. In P. Collins \& D. Lee (Eds.), The clause in English (pp. 273-294). John Benjamins. https://doi.org/10.1075/slcs.45.18sti

\section{Corpus}

Balanced Corpus of Contemporary Written Japanese (BCCWJ)

https://chunagon.ninjal.ac.jp/bccwj-nt/search

Developed by the National Institute for Japanese Language and Linguistics.

' The following abbreviations are used in glosses: ACC: accusative, ALL allative, BEN: benefactive, COM: comitative, COND: conditional CONN: connective, COP: copula, FOC: focus, FP: final particle, IMP: imperative, INS: instrumental, INT: intentional INTJ: interjection, LCTN: low certainty, LOC: locative, NMLZ: nominalizer/nominalization, NOM: nominative, PL: plural, PLT: polite, PROG: progressive PROH: prohibitive, Q: question particle/marker, QT: quotative, RES: resultative, RQ: rhetorical question, TEM: temporal, TOP: topic VOL: volitional

ii The conditional conjunction - $b a$ generally follows a verb or an adjective in the form of $-(r) e b a$. From a morpheme perspective, the verb connecting with - ba should be analyzed as three parts: (1) verb base, (2) auxiliary ( $r) e_{\text {, }}(3)$ suffix - $b a$. Some researchers treat them as two parts: (1) verb base, (2) suffix with the form of -(r)eba. Despite the existing viewpoints, this paper treats a verb connecting with -ba as two parts: (1) verb base including auxiliary (r)e, (2) suffix $-b a$. I treat them in that way to highlight the $-b a$ and to make the gloss concise to read. This treatment may not follow a morphology perspective.

iii Jiang (2020) was an exceptional study. He discussed subtype B-2 but did not mention subtype B-1.

iv Mithun (2008) used glosses as the following meanings: SUBJ: subject, CL: (valency) classifier, MIR: mirative, NMZ: nominalizer, PRF: perfective, DEP: dependent.

Mithun's (2008) also marked the information of tone in glosses. This paper omitted that information. 